Maria Chodkowska

Uniwersytet Marii Curie-Skłodowskiej

Renata Bednarz-Grzybek

Uniwersytet Marii Curie-Skłodowskiej

\title{
Problemy adaptacji dziecka w okresie międzywojennym
}

\begin{abstract}
Child Adaptation Problems in the Interwar Period
The study revolves around issues of child adaptation in the pedagogics of Janusz Korczak. The consecutive parts of the article focus on the problems of child adaptation to institutions i.e. orphaned children to educational centres as well as school conditions in general. The authors of the study pay close attention to the issue of child adaptation in his/her family and the local, urban and rural environments.
\end{abstract}

Keywords: Janusz Korczak, adaptation, education

\section{Wprowadzenie}

Adaptacja łączy się integralnie z rozwojem, jest jego warunkiem koniecznym. Najogólniej oznacza każdy proces, w którym zachowanie lub doświadczenie podmiotu zmienia się, aby dopasować się do zmian środowiska lub okoliczności, bąź jako reakcja na nacisk spoteczny ${ }^{1}$. Wiąże się tym samym z każdym procesem socjalizacji i tej jej części, która obejmuje działania uświadomione i zaplanowane intencjonalnie, czyli z wychowaniem. Przebieg adaptacji decyduje o efektach socjalizacji zarówno rozumianej jako proces, jak i stan będący jego rezultatem. Stąd teoretycy, jak i praktycy wychowania problemom adaptacji w rozwoju dziecka poświęcali sporo uwagi, rozumiejąc, że proces ten można wspierać, optymalizując w ten sposób efekty wychowania, lub przeciwnie bariery

${ }^{1}$ A. M. Colman, Stownik psychologii, Wydawnictwo Naukowe PWN, Warszawa 2009, s. 4. 
środowiskowe mogą stawać się dla niego przeszkodą, wpływać na poziom funkcjonowania dziecka, także w okresach jego dorosłości.

Jednym z pedagogów dostrzegających wagę wyżej wymienionych kwestii był Janusz Korczak. W niniejszym artykule prześledzimy problemy adaptacji dziecka w jego pedagogice. Kolejne części koncentrować się będą na problemach adaptacji dziecka do warunków instytucjonalnych, tj. dziecka osieroconego do warunków placówki wychowawczo-opiekuńczej oraz dziecka w ogóle do warunków szkoły. Następnie prześledzimy zagadnienie adaptacji dziecka w jego środowisku życia, rodzinnym i lokalnym, z uwzględnieniem specyfiki środowisk miejskich i wiejskich. Wreszcie spróbujemy odnieść spostrzeżenia i wskazania Korczaka do współczesnego wychowania zarówno tego instytucjonalnego, jak i rodzinnego.

\section{Problemy adaptacji dziecka osieroconego do warunków instytucji wychowawczo-opiekuńczej}

Naturalnym środowiskiem każdego dziecka jest rodzina, w której może ono harmonijnie wzrastać, nabywając kolejne kompetencje niezbędne do radzenia sobie z coraz bardziej odpowiedzialnymi obowiązkami i wyzwaniami, jakie stawiają przed nim różne kręgi jego społecznego uczestnictwa. Podejmowanie kolejnych ról ucznia, uczestnika grup rówieśniczych, później ról typowych dla dorosłego w warunkach prawidłowo funkcjonującej rodziny wymaga od dziecka sporo wysiłku, jednak ze względu na wsparcie bliskich, dokonuje się według wzorów czyniących jego sytuację przewidywalną i bezpieczną ${ }^{2}$ Zupełnie inaczej przebiega adaptacja do wymogów środowiskowych dziecka pozbawionego takiego wsparcia ${ }^{3}$. Jego sytuacja wymaga działań wychowawczo-opiekuńczych, które wprawdzie nie zastąpią rodziny, ale mogą w dużym stopniu kompensować dziecku jej niedobór. Stąd są one przedmiotem szczególnej troski pedagogów.

Janusz Korczak koncentrował swoją uwagę na dzieciach pozbawionych wsparcia rodzinnego ${ }^{4}$. Było to spowodowane nędzą, bezrobociem, pijaństwem w środowisku z jakiego się wywodziły. Większość z nich trafiała do przytułków lub dorastała na ulicy ${ }^{5}$. Nieliczni mieli szczęście stać się wychowankami pierwszych zakładów opiekuńczo-wychowawczych, jakie na terenie Warszawy zorganizował Korczak. Wiedział, że jego praktyczne działania, to tylko „kropla w morzu potrzeb”. W swojej twórczości podejmował wątki adaptacji wszystkich kategorii dzieci osieroconych w znaczeniu biologicznym i społecznym. Przez opisy sytuacji „dzieci ulicy” chciał zwrócić uwagę na ten palący

2 J. Korczak, „Nasz Dom” (z „,Gazetki Światecznej”'1921, nr 1/2, s. 9-11), w: idem, Prawidła życia. Publicystyka dla dzieci, Dzieła, t. 11, Międzynarodowe Stowarzyszenie im. Janusza Korczaka i Instytut Badań Literackich PAN, Warszawa 2003, s. 236.

${ }^{3}$ Dokumentacja Domu Sierot, w: Myśl pedagogiczna Janusza Korczaka. Nowe źródta, t. 2, wybór M. Falkowska, Nasza Księgarnia, Warszawa 1983, s. 193; J. Korczak, „Nasz Dom ’..., s. 237-238.

${ }^{4}$ Dokumentacja Domu Sierot..., s. 210-211.

5 A. Lewin, Korczak znany i nieznany, EZOP; WSP ZNP, Warszawa 1999, s. 151-152. 
wówczas problem społeczny. Z kolei przez analizę funkcjonowania zorganizowanych przez siebie pierwszych placówek wychowawczo-opiekuńczych udowadniał, że można i warto takim dzieciom stwarzać szanse prawidłowego rozwoju.

Wzorcowymi placówkami opiekuńczymi założonymi przez Janusza Korczaka były: Dom Sierot i Zakład Wychowawczy „Nasz Dom”. Pierwszy z nich, zlokalizowany na ulicy Krochmalnej 92, powstał w 1912 r. ${ }^{6}$ Doktor tworzył go od podstaw i czuwał nad rozwojem placówki przez prawie 30 lat $^{7}$. Według niego zakład ten miał zapewniać wychowankom klimat bezpieczeństwa, stabilności i prywatności ${ }^{8}$. Zgodnie z Regulaminem zapewniał całkowitą, bezpłatną opiekę najuboższym sierotom i półsierotom żydowskim w wieku od 7 do 14 lat ${ }^{9}$. Dom Sierot był także domem pracy i szkołą życia, stwarzał możliwość przygotowywania się dziecka do pracy zarobkowej ${ }^{10}$. Korczak uważał, że sposób jej wykonywania jest głównym miernikiem pozycji i wartości wychowanków ${ }^{11}$. We wspólnocie zakładu obowiązywały zasady sprawiedliwości, braterstwa, równych praw i obowiązków ${ }^{12}$. Zatrudniono tylko 3 dorosłe osoby: stróża, kucharkę i praczkę, ponadto pracowało tam 2 wychowawców. Większość prac dzieci wykonywały samodzielnie ${ }^{13}$.

Instytucjonalne wychowanie Korczak łączył z kształceniem. W zakładzie funkcjonowała dwuoddziałowa szkoła, kształcąca w zakresie niższych klas szkoły powszechnej. Prowadził ją Zarząd Gminy Starozakonnych, wynajmujący w tym celu cztery izby lekcyjne w Domu Sierot ${ }^{14}$. Zwykle uczyło się tutaj około 60 wychowanków Domu Sierot razem z dziećmi z miasta ${ }^{15}$. Przy Domu Sierot tworzono także tzw. ogniska dla starszych, samodzielnych już wychowanków ${ }^{16}$. Korczak stosował rozwiązania przybliżające wychowanków do życia ${ }^{17}$.

Druga placówka korczakowska „Nasz Dom” na Bielanach w Warszawie powstała w 1919 r. we współpracy z Maryną Falską. Formalnie to ona była kierowniczką zakładu, ale system wychowania w „Naszym Domu” rozwijał się w dużej mierze pod wpływem

${ }^{6}$ Dokumentacja Domu Sierot..., s. 192, 194.

7 J. Korczak, Pamiętnik, w: idem, Wybór pism, wyboru dokonał I. Newerly, Nasza Księgarnia, Warszawa 1958 , t. 4, s. 592.

${ }^{8}$ M. Chodkowska, R. Bednarz-Grzybek, Twórczość i praktyka pedagogiczna Janusza Korczaka w kontekście teorii socjologicznej Floriana Znanieckiego, Wydawnictwo UMCS, Lublin 2014, s. 209.

9 Dokumentacja Domu Sierot..., s. 249.

10 Ibidem, s. 193; A. Lewin, Korczak znany i nieznany..., s. 71-74.

${ }^{11}$ A. Lewin, Korczak znany i nieznany..., s. 211; M. Chodkowska, R. Bednarz-Grzybek, Twórczość i praktyka pedagogiczna..., s. 208.

12 A. Lewin, Korczak znany i nieznany..., s. 75; Dokumentacja Naszego Domu..., s. 302.

13 Dokumentacja Domu Sierot..., s. 197.

14 Ibidem.

15 A. Lewin, Korczak znany i nieznany,,,, s. 267; Dokumentacja Domu Sierot..., s. 197; Pamiętnik Towarzystwa „Pomoc dla Sierot” w Warszawie za rok 1913, Warszawa 1914, s. 24-27, 28.

${ }_{16}$ Dokumentacja Domu Sierot..., s. 204-208.

17 Ibidem, s. 197; Dokumentacja Naszego Domu..., s. 297; A. Lewin, Korczak znany i nieznany..., s. 272 . 
inspiracji i przy stałym współudziale Korczaka ${ }^{18}$. Nie było to mechaniczne kopiowanie tego, co działo się w Domu Sierot, raczej sprawdzanie i weryfikowanie pewnego modelu wychowania internatowego. Nasz Dom był instytucją otwartą na środowisko, mieściła się w nim świetlica dla niezamożnej młodzieży szkolnej i pozaszkolnej, organizowano półkolonie, wydawano bezpłatne obiady, funkcjonował oddział biblioteki publicznej.

W swoich zakładach opiekuńczo-wychowawczych Janusz Korczak stworzył małe społeczeństwa dziecięce, które rządziły się własnymi prawami, posiadały własne instytucje i organizacje, odrębne formy i metody samorządnego życia ${ }^{19}$. Uważał, że każde dziecko sieroce jest na swój sposób nieprzystosowane, stąd zachodzi konieczność jego readaptacji, ponownego przystosowania w zmienionym układzie warunków psycho- i socjopedagogicznych. Tej ponownej adaptacji powinno służyć wychowanie, rozumiane jako celowo i świadomie organizowany proces, w którego wyniku zachodzą ciągłe zmiany w osobowości ucznia wychowanka"20. Wychowanie powinno wspierać, a nie ograniczać, stąd w placówkach organizowanych przez Korczaka główną rolę w adaptacji do życia społecznego miały odegrać struktury samorządności dziecięcej²1.

Ważną instytucją w placówkach opiekuńczo-wychowawczych organizowanych przez Korczaka były sądy koleżeńskie. Miały one zniwelować wpływ humorów wychowawców czy opiekunów na los dzieci. Wprowadzały pewne normy w życie gromady, regulujące atmosferę i klimat współżycia mieszkańców zakładu. Miały także zainteresować wspólnymi sprawami zespół dziecięcy, i każdego wychowanka z osobna. Rozbudzały głęboką refleksję moralną nad czynami już popełnionymi. Uczyły samokrytycyzmu i tolerancji wobec praw drugiego człowieka, kształtowały opinię społeczną, przechodząc stopniowo od „groźnego paragrafu” do obowiązku moralnego. Uczyły wartościowania i poszukiwania kryteriów właściwej oceny, kształtowały zrozumienie prawa i społecznego obowiązku, kładły podwaliny pod ukształtowanie wzorowej postawy etycznej wychowanków $^{22}$. Taka postawa stwarzała duże szanse na harmonijne wchodzenie wychowanków w kolejne role życiowe, także przyszłe, wiążące się z wejściem w dorosłość.

Plany wprowadzania wychowanków w różne struktury życia społecznego Korczak oparł na logicznej i nowatorskiej koncepcji wychowania. Jej myślą przewodnią było uznanie autonomii i godności małego człowieka, odwołanie do zaufania, miłości, szacunku i porozumienia między dzieckiem a dorosłym. Chodziło o wszechstronne zaspokojenie jego potrzeb przez współrządzenie. Na terenie placówki działały: Rada Samorządo-

${ }^{18}$ Dokumentacja Naszego Domu..., s. 299.

19 J. Korczak, Jest szkoła, w: idem, Pisma wybrane, t. 3, wybór A. Lewin, Nasza Księgarnia, Warszawa 1978 , s. t. 3, s. 187-210.

${ }^{20}$ M. Jakubowski, Koncepcja Korczakowskiego samorządu wychowawczego, w: O pedagogike jako naukę o człowieku w setna rocznice urodzin Janusza Korczaka, Uniwersytet Śląski, Katowice 1979, s. 51.

${ }^{21}$ M. Chodkowska, R. Bednarz-Grzybek, Twórczość i praktyka pedagogiczna..., s. 206; J. Korczak, Jak kochać dziecko, w: idem, Pisma wybrane, t. 1, wprowadzenie i wybór A. Lewin, Nasza Księgarnia, Warszawa 1978, s. 296-352.

22 J. Korczak, Internat, Kolonie letnie, Dom Sierot, w: Wybór pism pedagogicznych, t. 1, red. E. Frydman, Warszawa 1957, s. 120; Dokumentacja Domu Sierot..., s. 252; M. Chodkowska, R. Bednarz-Grzybek, Twórczość i praktyka pedagogiczna..., s. 211. 
wa, Sąd Koleżeński oraz Sejm Domu Sierot ${ }^{23}$. Dzięki tym instytucjom dzieci uzyskały prawo porozumiewania się z dorosłymi i współdecydowania o zasadach życia w Domu. Współdecydowanie w naturalny sposób generowało współodpowiedzialność, stanowiącą kolejny wymóg prawidłowej adaptacji do struktur społecznych. W placówkach, organizowanych przez Janusza Korczaka, była ona realizowana przez współgospodarzenie (dyżury $)^{24}$, oddziaływanie opinii społecznej przejawiające się w przemyśleniach, komu jaki dyżur powierzyć, w plebiscytach życzliwości ${ }^{25}$, wyrokach sądowych ${ }^{26}$.

Korczak przeciwstawiał się wpajaniu dyscypliny za pomocą kar cielesnych, potępiał praktyki zawstydzania dziecka. Proponował system zachęt, odwołujący się do instytucji samorządu dziecięcego. Negował wszelkie formy rygoryzmu i bezduszności w relacjach opiekun-wychowanek ${ }^{27}$.

Samorządność stanowiąca jedną z głównych idei pedagogiki Janusza Korczaka, sprzyjała samodoskonaleniu się w procesie wychowawczym przez stwarzanie sytuacji do wykazywania się inicjatywą. Mały człowiek w założeniach tej pedagogiki miał być równorzędnym partnerem opiekuna. Przekształcanie Domu Sierot w idealną dziecięcą społeczność organizowaną i rządzoną przez same dzieci miało na celu zapewnienie im pełni samodzielnego rozwoju, usunięcie narzuconej przez społeczeństwo formalnej zależności wychowanka od wychowawcy, pobudzenie dziecka do refleksji nad sobą, a także uczenie samokrytycyzmu i właściwej postawy etycznej. Kształtowała się ona, m.in. przez instytucję Sądu Koleżeńskiego, gdzie wychowankowie wspólnie z opiekunami rozstrzygali spory zarówno pomiędzy sobą, jak i spory, w których stronę stanowili dorośli.

Duże znaczenie w procesie wychowania instytucjonalnego spełniała wprowadzona przez Korczaka Rada Samorządowa, podejmująca prace mające walor profilaktyki wychowawczej ${ }^{28}$. Jej celem było regulowanie współżycia jednostek i grup, aktywizowanie społecznej opinii, inicjowanie młodzieży do działalności, przez co stawała się ona instytucją zaspokajającą rzeczywiste jej potrzeby i dążenia do samorządnego życia. Tym samym Korczak znalazł rozwiązanie wielu zagadnień ściśle związanych z aktywizacją i uspołecznieniem wychowanków ${ }^{29}$. Samorządność młodzieży nie prowadziła w tym systemie do chaosu i anarchii. Korczak uznawał kierowniczą rolę wychowawcy opiekuna oraz potrzebę dyscypliny i karności w wychowaniu. Miała to być jednak taka karność, w której tworzeniu i przestrzeganiu uczestniczyliby sami wychowankowie. Umiejętność

${ }^{23}$ G. Walczak, Metody wychowania dziecka trudnego w ujęciu Janusza Korczaka, w: O pedagogikę..., s. 99-100; J. Korczak, Jak kochać dziecko, w: idem, Pisma wybrane, t. 1, s. 311-352.

${ }^{24}$ G. Walczak, Metody wychowania dziecka trudnego ..., s. 100-101.

25 Ibidem, s 104.

26 J. Korczak, Prawidła życia..., s. 80-81; Dokumentacja Domu Sierot..., s. 250-251; Dokumentacja Naszego Domu..., s. 308-310.

27 Opowieść o Januszu Korczaku. Człowiek, który stat się legendą, IBIS, Poznań 2013, s. 46; J. Korczak, Wychowawca ambitny, ,Szkoła Specjalna”1938/1939, t. 15, nr 1, w: idem, Wybór pism, t. 4, wyboru dokonał I. Newerly, Nasza Ksiegarnia, Warszawa 1958, s. 346-351; J. Korczak, Niepoprawni, [,, Szkoła Specjalna” 1931/1932, t. 8, nr 3], w: idem, Wybór pism, t. 4, s. 327-332; G. Walczak, Metody wychowania ..., s. 97-99.

28 Dokumentacja Naszego Domu..., s. 310-312.

${ }^{29}$ M. Jakubowski, Koncepcja Korczakowskiego samorządu..., s. 64. 
świadomego podporządkowywania się przyjętemu przez większość prawu znalazło praktyczny wyraz w ogólnej organizacji pracy opiekuńczo-wychowawczej Domu Sierot i Naszego Domu ${ }^{30}$. Oprócz Rady Samorządowej i Sejmu Dziecięcego funkcjonowała w nich Rada Pedagogiczna - zespół dorosłych - odpowiedzialna za jednolity kierunek wychowania, za opiekę i rozwój każdego dziecka ${ }^{31}$.

Samowychowanie i samorządność pomagały wychowankom w adaptacji do struktur społecznych, jakich wcześniej nie znali ${ }^{32}$. Struktury te w pełni odpowiadały ich potrzebom, o czym świadczyło duże zainteresowanie uczestnictwem w obradach sądów koleżeńskich czy redagowaniem pisma dziecięcego ${ }^{33}$. Przez takie rodzaje aktywności nabywali umiejętności rozmowy, stawiania i egzekwowania zadań, wdrażałli się do pracy i do życia w grupie, a wszystko to sprzyjało szybkiej i harmonijnej adaptacji w środowisku ${ }^{34}$. Dzieci adaptowały się do życia nie tylko wśród rówieśników, lecz także i dorosłych, a z drugiej strony dorośli musieli nauczyć się, że dziecko ma godność osoby ludzkiej i prawa przysługujące każdemu człowiekowi, ale także prawa specyficzne, przynależne dzieciom $^{35}$.

Korczak często podkreślał i konsekwentnie wdrażał myśl sprowadzającą się do stwierdzenia, że w adaptacji do środowiska społecznego, w przygotowanie do pełnienia w nim różnych ról bardzo duże znaczenie odgrywa praca. Szacunek dla pracy i dbałość o narzędzia pracy były kwestią niezwykłej wagi w jego systemie wychowawczym. Dla adaptacji wychowanków ważna była także kształtowana w tym systemie postawa poszanowania cudzej własności i norm obowiązujących w danym środowisku ${ }^{36}$. Korczak nie uznawał różnicy między pracą umysłową i fizyczną. Uczył, że szacunek do człowieka powinna wzbudzać nie praca czysta czy brudna, którą on wykonuje, ale rzetelny stosunek do obowiązków. Miernikiem wartości człowieka jest praca pożyteczna dla społeczeństwa. Jest nie tylko obciążeniem, ale możliwością zaspokajania ludzkich potrzeb, niosącą radość i przyjemność, budzącą uznanie. Na takie uznanie zasłużyć mogą nie tylko dorośli, ale również dzieci, nie tylko wówczas kiedy odniosą sukces, ale także kiedy wytrwale dążą do wspólnego dobra, tak jak mali bohaterowie z utworów Korczaka: Maciuś37,

\footnotetext{
30 Dokumentacja Domu Sierot..., s. 186-285; Dokumentacja Naszego Domu..., s. 288-331.

${ }^{31}$ M. Jakubowski, Koncepcja Korczakowskiego samorząu..., s. 65-66; Dokumentacja Domu Sierot..., S. 291-293.

32 A. Lewin, Korczak znany i nieznany..., s. 295.

33 J. Korczak, „Nasz Dom”..., s. 239; J. Korczak, Kodeks Sądu Koleżeńskiego w Naszym Domu w Pruszkowie, , Gazetka Świąteczna” 1921, nr 5, s. 36-39, w: idem, Prawidła życia..., s. 241-245.

${ }^{34}$ B. Smolińska-Theiss, Spuścizna pedagogiczna Janusza Korczaka. Pytania o uniwersalność i aktualność idei, w: Rok Janusza Korczaka 2012. Nie ma dzieci-są ludzie, Biuro Rzecznika Praw Dziecka, Warszawa 2013, s. 75 .

35 Ibidem; J. Korczak, Prawidła życia..., s. 17-19.

${ }^{36}$ A. Wernik, Wychowawcza funkcja publicystyki prasowej Janusza Korczaka dla dzieci w świetle materiałów z czasopisma „W słońcu”, w: O pedagogikę..., s. 173; A. Szlązakowa, Humanistyczne wartości książek Janusza Korczaka dla dzieci i młodziėzy, w: Życie i twórczość Janusza Korczaka jako temat filozoficzno-pedagogicznej refleksji, red. A. Tchorzewski, Wydawnictwo Uczelniane WSP Bydgoszcz, Bydgoszcz 1979, s. 106-107; Dokumentacja Domu Dziecka..., s. 227-231.

37 J. Korczak, Król Maciuś Pierwszy: powieść, Towarzystwo Wydawnicze, Warszawa 1923.
} 
i Dżek ${ }^{38}$. Najważniejsze jest, by działania te uczyły odwagi, występowania w obronie sprawiedliwości, walki o dobre imię, o dobrą sprawę.

Jednym z najważniejszych warunków harmonijnej adaptacji jest możliwość mówienia i bycia wysłuchanym. Korczak swoim wychowankom stwarzał takie możliwości zarówno $\mathrm{w}$ formach bezpośrednich, jak i pośrednich. Formy bezpośrednie otwierania się dziecka, mówienia o własnych problemach, formułowania opinii i ocen, dokonywały się w placówkach korczakowskich przez bogate rodzaje dyskursów, w których dziecko było partnerem nie tylko rówieśników, ale i dorosłych. Realizowały się one przez aktywny udział dzieci w strukturach samorządowych, jak też i przez rozmowy, dotyczące wszystkich kwestii, które były dla nich na tyle ważne i trudne, iż potrzebowały o nich mówić i szukać wsparcia wychowawców w ich rozwiązywaniu. Formy pośrednie swobodnych wypowiedzi dziecięcych realizował Korczak przede wszystkim przez zorganizowanie i wydawanie czasopisma, które dzieci same redagowały ${ }^{39}$. Zyskiwały możliwość publicznego wypowiadania się i uczyły się współodpowiedzialności za wspólne sprawy ${ }^{40}$. Był to równocześnie swoisty rodzaj kompensacji dla części wychowanków, ponieważ większość z nich nie potrafiła mówić przed audytorium, natomiast wypowiedzi pisemne były dla nich zadaniem łatwiejszym ${ }^{41}$.

\section{Problemy adaptacji dziecka do warunków szkoły}

Ważnym środowiskiem życia dziecka zarówno wychowywanego w rodzinie, jak i pozbawionego opieki rodzinnej, powinna być szkoła. Za czasów Korczaka nie była ona dostępna dla każdego dziecka. Także te, które do niej trafiały, miały duże trudności, by odnaleźć się w warunkach jakie stwarzała. Korczak pamiętał szkołę z własnych doświadczeń i przeżyć. Zawsze był nadwrażliwy, uczuciowy, wątły i delikatny ${ }^{42}$. Trudno mu się było pogodzić z realiami życia, dlatego czuł się świetnie w krainie wyobraźni ${ }^{43}$. Jego sprzeciw wzbudzała „czarna pedagogika”, którą stosowano w placówkach w okresie międzywojnia. Polegała na wzbudzaniu w uczniach strachu. Istniał cały wachlarz dotkliwych kar, z których najłagodniejszymi były drwiny, wrzaski, wyzwiska czy bicie linijką po rękach ${ }^{44}$. Do takiej szkoły trudno się było uczniom przyzwyczaić i przyjąć ją bezkrytycz-

38 J. Korczak, Bankructwo małego Dżeka, Towarzystwo Wydawnicze, Warszawa-Kraków 1924.

39 J. Korczak, O gazetce szkolnej, w: ibidem, Wybór pism, t. 4, s. 195-212.

${ }^{40}$ Dokumentacja Naszego Domu, s. 312-315; J. Korczak, Jest szkoła..., s. 190-205; J. Korczak, O gazetce szkolnej, w: idem, Wybór pism ..., s. 195-212; G. Walczak, Metody wychowania ..., s. 103-104; J. Korczak, Z naszego domu [,,W Słońcu” 1920, nr 1], w: idem, Wybór pism..., s. 265-266.

${ }^{41}$ Zob. J. Korczak, Tęsknota [,,W Stońcu” 1920, nr 10-11], w: idem, Wybór pism..., s. 279-281.

42 Opowieść o Januszu Korczaku..., s. 14.

43 Ibidem.

${ }^{44}$ Ibidem, s. 17; J. Korczak, Kiedy znów będę mały, w: Tenże, Pisma wybrane, t. 3, Nasza Księgarnia, Warszawa 1978, s. 271-406; J. Korczak, Pamiętnik, cyt. za J. Olczak-Ronikier, Korczak. Próba biografii, W.A.B., Warszawa 2011, s. 60. 
nie, w związku z tym Korczak przez całe życie zarówno w teorii, jak i w praktyce pedagogicznej sprzeciwiał się tej konserwatywnej tradycyjnej szkole ${ }^{45}$.

Korczak był przekonany, że każda działalność pedagogiczna powinna opierać się na obserwacjach prowadzących do stawiania diagnozy, co dotyczy także wspierania procesu adaptacji dziecka do różnych struktur społecznych. Praca w instytucji oświatowej, w szkole, w internacie, w zakładzie wychowawczym stanowi sposobność do czynienia obserwacji. Zachowanie się dzieci nasuwa liczne pytania ogólne i szczegółowe oraz uświadamia, że teoria pedagogiczna nie dostarczyła jeszcze na każde z nich odpowie$\mathrm{dzi}^{46}$. Pedagog musi radzić sobie sam, patrząc na reakcję swoich wychowanków, na to, kto pierwszy, a kto ostatni wybiega na przerwę, które dzieci wracają do domu samotne, parami, a które i dlaczego wykazują brak zainteresowania ${ }^{47}$. Powinien protokołować, notować własne myśli, stawiać pytania, gdyż bez nich nie nabywa wiedzy i doświadczenia $^{48}$. Obserwacja zachowania dziecka pozwoli na dostrzeżenie i zrozumienie, jakie bariery stanowią przeszkodę $\mathrm{w}$ adaptacji w konkretnej grupie rówieśniczej bądź instytucji.

Korczak rozumiał, że zadaniem szkoły jest nauczanie, ale jednocześnie walczył o to, by funkcja ta nie przesłoniła innych, równie ważnych, w tym wychowania wspierającego rozwój emocjonalny i społeczny dziecka. Wiedział, że jest to problem szkoły jako takiej, a nie tylko warunków polskich. Krytykował wady i braki różnych systemów oświatowych na świecie ${ }^{49}$. Zwracał uwagę na przeciążenie nauką, złe samopoczucie dziecka w szkole. Pisał o tych kwestiach, m.in. w Feralnym tygodniu ${ }^{50}$, w Szkole życia ${ }^{51}$. Podejmował tam dręczące dzieci i młodzież problemy, jak chociażby kwestię strachu przed wezwaniem do odpowiedzi. Lęk towarzyszył dzieciom także w sytuacji, gdy uzyskiwały negatywne oceny, ponieważ obawiały się reakcji ze strony rodziców. Utwory Korczaka dotyczyły także relacji nauczyciel - uczeń, przeciążenia programów szkolnych, donosicielstwa na terenie szkoły, przedmiotowego traktowania uczniów, roli dyżurnych na terenie szkoły występujących często w charakterze dyktatorów.

Według Korczaka szkoła ma być dostępna dla wszystkich dzieci. Co więcej, opieka szkolna powinna być rozszerzana także na okresy nie objęte nauką, tzn. wstępującego do szkoły wychowanka należy wysyłać na kolonie, aby lepiej można było go poznać, posta-

\footnotetext{
45 Opowieść o Januszu Korczaku..., s. 46. Por. M. Chodkowska, R. Bednarz-Grzybek, Twórczość i praktyka pedagogiczna..., s. 214-216.

46 J. Korczak, Momenty wychowawcze, w: Pisma wybrane, t. 3, s. 212; J. Korczak, Życzliwość i niechęć, [,Wychowanie Przedszkolne” 1933, $n r$ 9, nr 4], w: idem, Wybór pism, t. 4, s. 375-379. Por. E. Lisowska, Wprowadzenie do diagnozowania pedagogicznego, Wydawnictwo Uczelniane Wszechnica Świętokrzyska, Kielce 2003, s. 57-62.

47 J. Korczak, Momenty wychowawcze..., s. 212-213; W. Bobrowska-Nowak, Metoda obserwacji klinicznej w ujęciu Janusza Korczaka i jej znaczenie dla współczesnej pedagogiki, w: O pedagogikę ..., s. 32-33.

48 J. Korczak, Pamiętnik, w: idem, Wybór pism, t. 4, s. 501-599; J. Korczak, Momenty wychowawcze..., s. 213-214; W. Bobrowska-Nowak, Metoda obserwacji..., s. 32-33; E. Lisowska, Wprowadzenie do diagnozowania..., s. 58-62.

49 J. Korczak, Jest szkoła ..., s. 187-189.

50 J. Korczak, Feralny tydzień, w: idem, Pisma wybrane, t. 3..., s. 28-55.

51 J. Korczak, Szkoła życia, w: idem, Pisma wybrane, t. 3..., s. 59-186.
} 
wić właściwą diagnozę wychowawczą i zdrowotną, co umożliwi wybranie odpowiedniej metody postępowania, a nawet sposobów leczenia, gdy dziecko jest chore i potrzebuje opieki lekarskiej ${ }^{52}$.

Korczak bardzo duże znaczenie przypisywał adaptacji dzieci do warunków szkoły. Uważał, że po przybyciu do niej każdy wychowanek powinien otrzymać opiekuna wybranego spośród dzieci, do którego obowiązków miało należeć zapoznanie nowicjusza z panującymi w szkole zwyczajami, z regulaminem, z zasadami współżycia w zespole ${ }^{53}$. Sprawowanie takiej opieki jest korzystne również dla starszego dziecka, uczy go dostrzegania innych ludzi, ich potrzeb i oczekiwań oraz kształtuje postawę gotowości niesienia im pomocy. Korczak apelował do dzieci, aby pomagały młodszym wychowankom w adaptacji do warunków życia zbiorowego, ale także, aby troszczyły się o swoich bliskich, o rodzeństwo, o rodziców, wskazywał, jak ta troska powinna się przejawiać ${ }^{54}$.

Adaptacji do warunków szkoły sprzyja podejmowanie i wykonywanie obowiązków. Ich charakter należy dostosowywać do indywidualnych zainteresowań i zdolności dziec$\mathrm{ka}^{55}$. Jeśli każdy ma przydzielone odpowiednie dla niego obowiązki, to uczniowie dzielą się między sobą spostrzeżeniami i uwagami na temat wykonywanych zadań i wykonują je chętnie. Ważne jest przy tym, by każdy mógł liczyć na pomoc i życzliwość ze strony kolegów $^{56}$. W ramach wykonywanych zajęć uczniowie powinni współpracować ze środowiskiem lokalnym, np. organizować inscenizacje bajek dla dzieci, opiekować się chorymi, wypożyczać książki, pomagać biednym ${ }^{57}$. W ten sposób adaptacja do warunków szkolnych staje się tożsama $\mathrm{z}$ adaptacją do warunków życia w szerszym środowisku. Przez takie kontakty uczniowie poznają prawa obowiązujące w społeczeństwie, uczą się rozróżniać co jest dobre a co złe, aby w razie potrzeby umieć się złu przeciwstawićs ${ }^{5}$. W szkole powinny obowiązywać prawa oparte na poszanowaniu ludzkiej godności w każdym dziecku i na szacunku dla jego indywidualnych zainteresowań ${ }^{59}$.

Niektóre z proponowanych przez siebie rozwiązań Korczak sprawdzał na kolonii w Michałówce oraz w Domu Sierot, a potem w Naszym Domu ${ }^{60}$. Wierzył, że upowszechnienie ich w szkole uczyniłoby ją środowiskiem bardziej przyjaznym dziecku, a jednocześnie lepiej wypełniającym funkcje socjalizacyjno-wychowawcze.

52 E. Lisowska, Wprowadzenie do diagnozowania..., s. 57; J. Korczak, Szkoła życia..., s. 91-96; Dokumentacja Domu Sierot..., s. 223-224.

${ }_{53}$ Dokumentacja Domu Sierot..., s. 250; J. Korczak, Szkoła życia..., s. 168-171; J. Król, Koncepcja szkoły życia Janusza Korczaka, w: O pedagogikę..., s. 84.

${ }^{54}$ A. Wernik, Wychowawcza funkcja publicystyki..., s. 172; Dokumentacja Domu Sierot..., s. $218,266$.

55 J. Korczak, Prawidła życia..., s. 70-75.

56 J. Korczak, Prawo dziecka do szacunku..., s. 62-63; Dokumentacja Naszego Domu..., s. 296-298.

57 Dokumentacja Domu Sierot..., s. 272-273.

58 J. Król, Koncepcja szkoły życia..., s. 85.

${ }^{59}$ Ibidem; S. Palczewska, Respektowanie praw dziecka w placówkach opiekuńczo-wychowawczych, w: Dziecko w koncepcjach pedagogicznych Marii Grzegorzewskiej i Janusza Korczaka, red. J. Bałachowicz, Wydawnictwo Akademii Pedagogiki Specjalnej, Warszawa 2012, s. 188-189; Dokumentacja Domu Sierot, s. 213-214.

${ }^{60}$ Dokumentacja Domu Sierot..., s. 276. 
Korczak krytykował szkolną wiedzę dla samej wiedzy, przeciążenie dzieci pracą, zaniedbanie wychowania fizycznego ${ }^{61}$. Jeszcze przed odzyskaniem niepodległości wypowiadał się przeciw rusyfikacji. Krytykę szkolnictwa początku XX w. przedstawił w artykule Szkoła współczesna ${ }^{62}$. Przeciwstawił się w nim hasłu, że szkoła ma za zadanie kształcić, a rodzina wychowywać ${ }^{3}$. Udowadniał, że współczesna mu szkoła wychowuje klerykalnych centrowców i patriotów szowinistów ${ }^{64}$, a władze za takie wychowanie obciążają tylko i wyłącznie rodziny. Kwestionował wartość świadectwa dojrzałości uzyskanego w szkole, realizującej proces kształcenia na podstawie przestarzałych programów nauczania ${ }^{65}$.

Szczególnie dużo barier adaptacyjnych do warunków szkoły przeżywało dziecko z rodziny ubogiej. Korczak podkreślał, że nawet bezpłatne szkoły dużo kosztują ${ }^{66}$. Znacznie łatwiej jest przystosować się do wymogów szkoły uczniowi, któremu na początku roku rodzice kupują wszystkie potrzebne książki i zeszyty, pantofle gimnastyczne i teczkę. Przykro jest natomiast prosić o to rodziców, którzy nie mają pieniędzy ${ }^{67}$. Dziecko z rodziny bogatej wyrywa stronice zeszytu, a zaplamiony zeszyt wyrzuca i nikogo nie obchodzi, że zgubiło ołówek. Z kolei dziecko z rodziny biednej pisze małymi literami, żeby na dłużej zeszytu starczyło. Bogate dzieci mają własny pokój albo przynajmniej stolik z szufladką na kluczyk. Mogą spokojnie odrabiać lekcje. Ubogie piszą zmarzniętą ręką przy lampce na kiwającym się stole, niedobrą stalką, bladym atramentem na tanim lichym papierze. Nie każdy przed pójściem do szkoły jadł śniadanie, w związku z czym może być zmęczony i senny ${ }^{68}$. To wszystko rodzi bunt, utrudnia, a nawet uniemożliwia adaptację do warunków szkoły, tym bardziej, że dzieci biedne często są odrzucane przez te z rodzin bogatszych ${ }^{69}$. W utworze Jak kochać dziecko Korczak pisał, że biedne dzieci są częściej brudne, mówią brzydkie wyrazy, mają wszy, chorują, można się od nich zarazić, biją się z kolegami, a to wszystko zniechęca do kontaktów i utrudnia przebieg procesów adaptacyjnych ${ }^{70}$. Krytykował nie tylko system szkolny, ale także nauczycieli, którzy w praktyce realizują założenia tego systemu ${ }^{71}$. Uważał, że to oni mogliby pomóc

${ }^{61}$ M. Chodkowska, R. Bednarz-Grzybek, Twórczość i praktyka pedagogiczna..., s. 224-227.

${ }^{62}$ J. Korczak, Szkoła wspótczesna, w: idem, Pisma wybrane, t. 3, wybór A. Lewin, Nasza Księgarnia, Warszawa 1978, s. 23-26.

63 Ibidem, s. 23.

64 Ibidem, s. 24.

${ }^{65}$ A. Łata, Wczesne utwory literackie Janusza Korczaka jako przejaw ksztaltowania się jego postawy patriotycznej, w: Życie i twórczość Janusza Korczaka..., s. 124; M. Chodkowska, R. Bednarz-Grzybek, Twórczość i praktyka pedagogiczna..., s. 227.

${ }^{66}$ J. Korczak, Prawidła życia..., s. 51-52.

${ }^{67}$ Ibidem, s. 52.

${ }^{68}$ Ibidem.

${ }^{69}$ Ibidem, s. 55.

70 J. Korczak, Jak kochać dziecko, w: J. Korczak, Pisma wybrane, t. 1, s. 164-165.

71 J. Korczak, Prawidła życia..., s. 39-44; J. Korczak, Dzieci i wychowanie, w: idem, Pisma wybrane, wybór A. Lewin, t. 3, s. 18-26; M. Chodkowska, R. Bednarz-Grzybek, Twórczość i praktyka pedagogiczna..., s. 219-220. 
dzieciom pochodzącym z różnych środowisk w adaptacji społecznej. Wymaga to spełniania przez nich określonych warunków: nauczyciel powinien kierować się empatią, pozytywnym myśleniem, być tolerancyjny i otwarty. Musi posiadać wiedzę ogólną i pedagogiczną, a przy tym dążyć do samorozwoju. Powinien być przygotowany nie tylko do nauczania określonej wiedzy, ale także do pracy psychologiczno-pedagogicznej z drugim człowiekiem $^{72}$.

\section{Problemy adaptacji dziecka w środowisku rodzinno-lokalnym}

Problemy adaptacji dziecka dotyczą nie tylko jego odnajdywania się w formach organizacji instytucjonalnej. Ujawniają się również w środowisku naturalnym wiążącym się z uczestnictwem rodzinno-lokalnym ${ }^{73}$. Korczak obrazował je na przykładzie zmian miejsca zamieszkania ${ }^{74}$. Były to sytuacje bardzo częste, ponieważ ludność mieszkająca w mieście pozbawiona była trwałego gniazda rodzinnego, mieszkania, które zajmowali nie były ich własnością, nie dawały poczucia stabilizacji i przynależności ${ }^{75}$. Miejsce, gdzie rodzina żyła było uzależnione od jej sytuacji materialnej w danym momencie. Utrata pracy, choroba, wypadki losowe zmuszały do przeprowadzania się do tańszych, mniejszych lokali o gorszych warunkach, bądź też na tereny, gdzie możliwe było znalezienie jakiejkolwiek pracy. Korczak uważał, że dzieci, pomimo ich zdolności adaptacyjnych wynikających z wieku, obawiają się zmian ${ }^{76}$. Przeprowadzki w nowe nieznane miejsca, z dala od znajomych i rówieśników wzbudzają u nich lęk ${ }^{77}$. Nie zawsze są w stanie zrozumieć, dlaczego rodzice muszą się wyprowadzić. Oczywiście dzieci są różne, w związku z czym te lęki także nie są powszechne. Dla niektórych dzieci zmiana środowiska jest przygodą, frajdą. Potrafią się z niej cieszyć nawet wówczas, kiedy widzą Łzy w oczach rodziców ${ }^{78}$. Być może mają nadzieję na wyzwolenie się od starych problemów, na nową lepszą jakość życia lub przynajmniej na przeżywanie czegoś nowego, przerywającego monotonię życia ubogiej rodziny. Jednak w wielu przypadkach konieczność wchodzenia w nowe środowisko, adaptacja do panujących w nim norm, walka o zdobycie w nim pozycji odpowiedniej do ambicji i możliwości, stanowiły źródło traumy i długotrwałego stresu. Specyficzne powiązanie rodziny i podwórka powodowały, że

72 J. Korczak, Teoria a praktyka [,,Szkoła Specjalna” 1924/1925, nr 2], w: idem, Wybór pism, t. 4, wyboru dokonał I. Newerly, Nasza Księgarnia, Warszawa 1958, s. 301-305; E. Januszewska, Pedagogika Korczaka $i$ współczesne problemy wychowania, „Problemy Opiekuńczo-Wychowawcze” 2003, nr 9, s. 56-58.

73 J. Korczak, Prawidła życia..., s. 68-69.

74 Ibidem, s. 15-16.

75 J. Korczak, Własność dziecka, [„,Nasz Przegląd” 1927, nr 10], w: Myśl pedagogiczna Janusza Korczaka. Nowe Źródła, wybór M. Falkowska, t. 2, Nasza Księgarnia, Warszawa 1983, s. 155-156.

76 J. Korczak, Prawidła życia..., s. 20.

77 Ibidem, s. 19.

${ }^{78}$ J. Korczak, Stawa, w: J. Korczak, Stawa. Opowiadania (1898-1914), Dzieła, t. 6, red. H. Kirchner [i in.], Oficyna Wydawnicza Latona, Warszawa 1996, s. 8. 
dzieci tęskniły za rówieśnikami ze starej dzielnicy. Jeśli zdążyły już uzyskać pewną pozycję, to traciły ją i musiały od nowa szukać dla siebie miejsca w nieznanych strukturach, co było wyzwaniem także i dlatego, że struktury te posiadały już hierarchie tworzoną przez „starych” mieszkańców.

Również zmiany przestrzeni fizycznej i lokalnej nie zawsze korzystnie wpływały na dziecko, któremu często w takich sytuacjach towarzyszył strach. Jak pisał Korczak, małe dziecko ma wiele pracy, zanim jest w stanie zrozumieć własny dom ${ }^{79}$. A jest to podstawa poznawania świata, dopiero bowiem gdy człowiek pozna własne mieszkanie, wtedy zaczyna myśleć o tym, co inaczej i daleko. Przy częstych zmianach miejsca zamieszkania dziecko musiało więc koncentrować energię i wysiłki, by się w tej nowej przestrzeni fizycznej odnaleźć. Tym bardziej, że zmiana przestrzeni mieszkania wiązała się z równoczesną zmianą jego najbliższego otoczenia - czyli podwórka ${ }^{80}$.

Podwórko, na ogół przypisane do miejskiej kamienicy, stanowiące wspólną przestrzeń poszerzającą terytorium ciasnych, przeludnionych mieszkań, spełniało w rodzinach proletariackich ważne funkcje socjalizacyjne. Przebywanie części mieszkańców, zwłaszcza dzieci na podwórku, poprawiało choćby na krótki czas warunki lokalowe dorosłych. Zapracowana matka jednego z bohaterów Sławy kierowała do dzieci słowa: Pijcie herbatę $i$ wynoście się na podwórko. I nie bawcie się z łobuzami ${ }^{81}$. Przestrzegać takich norm byłoby jednak bardzo trudno nawet dzieciom wykazującym chęć podporządkowania się nakazom i zakazom dorosłych. Podwórko było terenem społecznych kontaktów rówieśniczych, ale i dzieci znacznie różniących się wiekowo. Był to obszar tworzenia się swoistej hierarchii, której podporządkowanie się było konieczne dla „przetrwania” i zdobycia pozycji, ale często wymagało odrzucania norm przekazywanych w rodzinie ${ }^{82}$. Takie odejście od wartości i norm wychowania rodzinnego było tym łatwiejsze, że rodzice pochłonięci pracą, najczęściej pozostawiali dzieci samym sobie. A na podwórku nikt ze starszych osób nie miał czasu się nimi zająć, powiedzieć im, co jest dobre, a co złe ${ }^{83}$.

Dzieci w ubogich rodzinach proletariackich często bywały głodne, w związku z czym szybko musiały dorastać i brać odpowiedzialność za zaspokajanie najbardziej elementarnych potrzeb własnych i potrzeb swoich bliskich. Ich problemy Korczak uosobił, m.in. w postaci bohatera Sławy - Władka. Chłopiec nie żalił się z tego powodu, gdyż bycie głodnym w jego przekonaniu oznaczało straszny wstyd ${ }^{84}$. Jednocześnie uczucie głodu w jego przypadku podziałało aktywizująco, wzmocniło mechanizmy adaptacyjne. Władek chcąc wesprzeć rodzinę, zdecydował się na podjęcie pracy. Dorabiał, prowadząc rachunki w sąsiednim sklepiku. W konsekwencji utracił prawo do beztroskiego dorastania, z natury przysługujące dzieciom i prawo do rozwijania posiadanych uzdolnień i zainte-

\footnotetext{
79 J. Korczak, Prawidła życia ..., s. 20-21.

${ }^{80}$ Ibidem, s. 27-28.

${ }^{81}$ J. Korczak, Stawa..., s. 9. Por. J. Korczak, Pedagogika żartobliwa, w: Wybór pism ..., t. 4, s. 152.

82 J. Korczak, Prawidła życia..., s. 78-81.

83 J. Korczak, Stawa..., s. 29.

${ }^{84}$ Ibidem, s. 19.
} 
resowań w procesie nauki szkolnej. Paradoksalnie jednak tracąc to wszystko, również dużo zyskał. W tym trudnym czasie bardziej związał się z rodzeństwem, poczuł się starszym bratem odpowiedzialnym za nie ${ }^{85}$. Taka świadomość częściowo przynajmniej kompensowała mu wysiłek przedwczesnego zarabiania na życie oraz konieczność rezygnacji ze szkoły, na edukację bowiem nie było pieniędzy w rodzinach, w których brakowało nawet chleba.

Bieda rodziny proletariackiej niekoniecznie musiała oznaczać jej patologię, chociaż często tak właśnie się zdarzało. Bezrobotni rodzice popadali w alkoholizm, a działania wychowawcze sprowadzały się wówczas do przemocy, bądź też dziecko przestawało być przez nich dostrzegane. Znajdowało wówczas wsparcie w środowisku ulicy, do którego musiało się adaptować, przejmując obowiązujące tam wartości i normy. Pełny obraz takiego środowiska i charakterystykę adaptacji do niego dzieci o różnych cechach osobowościowych przedstawił Korczak w powieści Dzieci ulicy ${ }^{86}$.

Dzieci ze środowiska biedoty warszawskiej umiały się w nim odnaleźć w zależności od cech charakteru łatwiej albo trudniej. Niektóre z nich marzyły o wyrwaniu się z życia w nędzy i lepszej przyszłości, i czasem się im to udawało, chociaż drogi ich adaptacji bywały różne, tak jak różne były ich charaktery. Dobrze obrazuje te odmienności adaptacyjne historia dwojga bohaterów Dzieci ulicy: Mańki i Antka. Oboje pochodzili z rodziny dotkniętej pijaństwem i wiążącą się z nim biedą. Zostały sprzedane hrabiemu Zaruckiemu i znalazły się w zupełnie nowych dla siebie warunkach. $Z$ jednej strony warunki te uświadamiały im, że są inne, gorsze, ale z drugiej - stwarzały szansę oderwania się od negatywnego dziedzictwa. Oboje tę szansę wykorzystali, chociaż adaptacja każdego z nich przebiegała inaczej. Mańka na nowe środowisko zareagowała lękiem, jednocześnie przyjmując postawę refleksyjną wobec swojej przeszłości. Potrafiła być krytyczna wobec matki. Twierdziła, że jest ona podła i tak chytra, że za sto rubli pozwoliłaby się bić87. Biła też, „za darmo” córkę, zmuszając małą dziewczynkę do usługiwania sobie i swoim kolejnym partnerom, głodziła ją i zmuszała do żebrania na ulicy. Tam Mańka poznała Antka, którego obdarzyła zaufaniem i była w stanie polubić 88 . Wyrwana ze środowiska ulicy, przebywając na dworze hrabiego, początkowo zamknęła się w sobie i postanowiła milczeć ${ }^{89}$. Nie lubiła książek, bo było w nich wiele rzeczy, których nie rozumiała i wiele kłamstw. Pokochała swoją samotność, opuszczenie i skryte myśli. Z czasem zaczęła się otwierać, o swoim życiu opowiedziała hrabiance Irenie, próbowała też wypowiadać się pośrednio, pisząc powieści. Odnalazła się w nowych obowiązkach. Na wsi, w której przebywała, hrabia otworzył żłobek i ochronkę. Wówczas dziewczynka poczuła się szczęśliwa, taka praca odpowiadała jej upodobaniom. W ciągu dnia przebywała w żłobku wśród dzieci, była łagodna i troskliwa. Adaptacja zawodowa zmieniła jej sto-

\footnotetext{
85 Ibidem, s. 20, 28.

${ }^{86}$ J. Korczak, Dzieci ulicy, w: idem, Dzieci ulicy. Dziecko salonu, Dzieła, t. 1, red. H. Kirchner [i in.], Oficyna Wydawnicza Latona, Warszawa 1992.

${ }^{87}$ Ibidem, s. 82.

88 Ibidem, s. 85- 86 .

${ }^{89}$ Ibidem, s. 191-192.
} 
sunek do opiekunów we dworze i do życia w ogóle, okazywała im szacunek i postępowała $\mathrm{z}$ rozwagą ${ }^{90}$. Zaangażowanie $\mathrm{w}$ pracę zmieniło percepcję jej osoby w odbiorze opiekunów. Hrabianka Irena zaczęła ją traktować jak towarzyszkę pracy, co wpłynęło na tworzenie się między nimi partnerskich relacji.

Przyjaciel Mańki, Antek, również trafił z ulicy w nowe środowisko dworu hrabiego, ale jego droga adaptacji była inna. Był chłopcem odważnym i samodzielnym, a jednocześnie zepsutym i upartym. Nie chciał krytycznie spojrzeć na swoją przeszłość, w jego mniemaniu nieźle mu było w domu ${ }^{91}$. Kiedy znalazł się we dworze hrabiego Zaruckiego, ładne ubrania nie zrobiły na nim wrażenia. Tęsknił za Warszawą, gdzie miał, jak twierdził, robotę. Uważał się za cwaniaka ${ }^{92}$, którego najlepiej nauczy życie. Jego rówieśnicy z ulicy, tzw. loniarze, czyli mali złodzieje, mieli według niego honor i umieli bronić tego honoru ${ }^{93}$. Nie zdradzali nigdy, że jest im źle, nie bali się nędzy. Nie lubili nic dostawać z łaski. Dlatego Antka ciągnęła do miasta jakaś ogromna siła. W końcu opuścił dwór na własne życzenie, aby wrócić do środowiska ulicy. Tam wraz ze swoim przyjacielem Józiem mógł zajmować się łapaniem zbłąkanych psów, by je potem zwracać za „sowitą nagrodę”, oszukiwaniem „litościwych osób”, wprowadzaniem gości do cyrku, oszukując czujność biletera. Antek zarabiał też dorywczymi zajęciami, pracował w cukierni, perfumerii, składzie tytoniu, handlu win, księgarni, wszędzie poszukując braterstwa, równości, życzliwości ${ }^{94}$. Stabilizację zaczął osiągać pod wpływem czytanych książek i znajomości ze starcem obłąkanym marzycielem ${ }^{95}$. Dostrzegł zagrożenia dawnego życia, zaczął odczuwać lęk przed dotychczasowym środowiskiem. Jego myśli wróciły do Mańki i dworu hrabiego, w którym wcześniej przez chwilę zagościł. Spotkał ponownie Mańkę, wspólnie podjęli decyzję o małżeństwie, udało im się ostatecznie zaadaptować do nowego środowiska. Drogi tej adaptacji różniły się, ale były podobne pod względem trudnych doświadczeń życiowych, przemyśleń i refleksji oraz ze względu na spotkanie na swojej drodze życia mądrych i życzliwych ludzi.

Bardzo szybki i stosunkowo łatwy był proces adaptacji innego bohatera Dzieci ulicy, o imieniu Jędrek. Chłopiec wzrastał w nędzy, mieszkał w opłakanych warunkach, był przy tym wątły i chorowity. Miał zamiłowanie do książek, czego nie była w stanie zrozumieć nadużywająca alkoholu matka. Dzięki rekomendacji Antka zajął się nim hrabia Zarucki, a chłopcu od razu udało się zerwać z przeszłością ${ }^{96}$. Zmarł przedwcześnie, a kontakty z nim uświadomiły hrabiemu, że wśród nędzarzy są materiały na cennych ludzi, byle opieka nad nimi istniała ${ }^{97}$.

\footnotetext{
90 Ibidem, s. 194-195.

91 Ibidem, s. 79.

92 Ibidem, s. 93.

93 Ibidem, s. 97.

94 Ibidem, s. 165.

95 Ibidem, s. 180.

96 Ibidem, s. 198.

97 Ibidem, s. 199.
} 
Jednak nie wszyscy bohaterowie Korczakowskiej powieści potrafili zerwać ze środowiskiem ulicy, jak np. chłopiec z rodziny szewskiej, który nie miał ochoty kontynuować ojcowskiego fachu i uciekł z domu ${ }^{98}$. Był przewodnikiem grupy „dzieci ulicy”. Wymyślał najlepsze kawały, miał najlepsze gołębie. Umiał pisać i czytać. Jako dwudziestolatek zarabiał pisaniem próśb i podań do sądów i do urzędów. Po stracie ojca, sprzedał warsztat, przepił pieniądze z kolegami i zajął się kradzieżą ${ }^{99}$. Został skazany na ulicę, nie potrafił się odciąć od tego środowiska. Podobnie było z Józkiem Bzikiem, dzieckiem wcześnie osieroconym i w wieku pięciu lat oddanym do ochrony. Czuł się tam źle. Twierdził, że jest mu ciasno i dlatego podjął decyzję o ucieczce. Wrócił na ulicę, o czym zadecydował pociag do przygód ciekawych podczas ciemnej nocy oraz do tej solidarności, która każe cierpieć, a nie wydać ${ }^{100}$.

Wstrząsający obraz życia dzieci w Warszawie na początku XX w. Korczak przedstawił także w innych utworach, m.in. w rozdziałach powieści Dziecko salonu: $\mathrm{Na}$ Solcu ${ }^{101}$, Noc $^{102}$, Wykolejony ${ }^{103}$, Dziwny świat ${ }^{104}$, Tomek Bitys ${ }^{105}$. Był uczulony na krzywdę dzieci z ulicy, na ich ciężki los i łatwe stawanie się obiektem wykorzystywania ze strony dorosłych. W felietonie Nie milusińscy ${ }^{106}$ pisał: Tu dzieci-nie milusińscy. Cenia ich prace, poszukuja. Majstrowie chętnie chłopakami orza $i$ duże magazyny $i$ duże fabryki orza dziećmi. Czeladnik chce zaraz rubla, dorosty chce być syty, a chłopak otrzymuje kat, obiad i piątkę-ustucha się $i$ boi. A przy tym zwinniejszy, chętniejszy... ${ }^{107}$. Taka sytuacja odbierała dziecku nie tylko życiowe szanse, ale w ogóle godność ludzką, i temu Korczak zdecydowanie się sprzeciwiał. Wiedział, że nieletni wyrobnicy, to dzieci żyjące w warunkach niezwykle trudnych, wręcz nieludzkich. Tłoczyły się w przeludnionych, małych, wilgotnych i ciemnych izbach, odżywiały się nieregularnie, posiłki były niewystarczające dla ich prawidłowego rozwoju. Problemem często był brak odpowiednich, dostosowanych do pór roku ubrań i butów ${ }^{108}$.

Podobne trudności przeżywały dzieci wiejskie, często wychowywane w rodzinach ubogich. One także ciężko pracowały od najmłodszych lat, ich rodzice zwykle nie akceptowali dziecięcych zabaw, widząc w nich przejaw lenistwa i próżniactwa. Potomstwo miało być przydatne w gospodarstwie, tylko wtedy można było je uznawać za pożyteczne. Trudne warunki życia na wsi, bieda pomimo ciężkiej pracy, pozwalająca jedynie na marną egzystencję sprawiały, że ludzie stawali się szorstcy i oschli. Cierpieli sami i nie

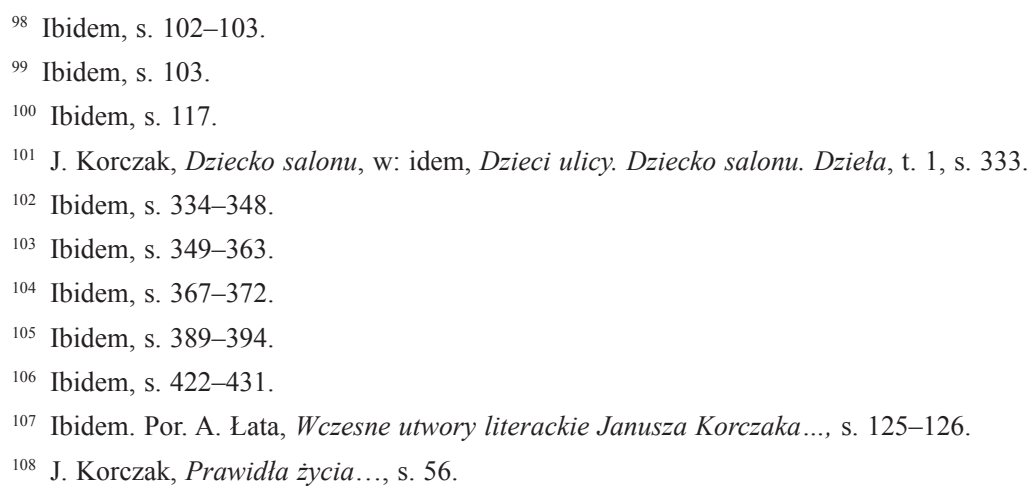


zwracali uwagi na cierpienia innych. Mieli świadomość, że także życie ich dzieci będzie bardzo ciężkie, więc ich nie oszczędzali, wierząc że tylko twardzi, silni, zahartowani i pracowici ludzie mogą stawiać czoła trudnej rzeczywistości, w której toczy się walka o przetrwanie. O jakości stosunków rodzinnych decydowały więc warunki życia, a nie brak uczuć rodzicielskich. Praca na rzecz gospodarstwa była łącznikiem między domownikami, dominowała funkcja ekonomiczna rodziny, której musiały zostać podporządkowane wszystkie pozostałe, w tym wychowawcza i opiekuńcza. Utrudniało to dziecku rozwijanie mechanizmów adaptacyjnych. Nie mając akceptacji i wsparcia najbliższych, z czasem godziło się ono z tym, że musi sobie samo radzić, stawało się nieufne wobec innych ${ }^{109}$. Prawidłowy przebieg socjalizacji utrudniała także atmosfera wielu środowisk wiejskich. Podobnie jak w miastach, obserwowano tam niską moralność przejawiającą się w notorycznym upijaniu się, przeklinaniu, braku zahamowań w kwestii obyczajów. Na porządku dziennym były kradzieże i bójki1"10. Problemy nasilały się również $\mathrm{z}$ uwagi na ciemnotę i zacofanie panujące $\mathrm{w}$ środowisku wiejskim, choroby nękające dzieci, wynikające z nieprzestrzegania podstawowych zasad higieny, niewłaściwego żywienia. Często przypisywano je złym mocom i zamiast leczyć, uciekano się do zabobonów i odczyniania uroków. Mimo fatalnego stanu opieki nad dzieckiem w rodzinach wiejskich, pojawiały się głosy, że sytuacja dziecka była tam i tak lepsza niż dzieci mieszkających w miastach. Rodzina wiejska była zdrowsza i bardziej zintegrowana niż rodzina wielkomiejska. Silnym elementem integrującym była w tym przypadku ziemia, stanowiąca wartość dla wszystkich jej członków. Dawała poczucie zakorzenienia, przynależności rodziny do określonego miejsca. Zespołowy charakter pracy w gospodarstwie powodował tworzenie się silniejszych i trwalszych więzi niż w rodzinach żyjących w miastach ${ }^{111}$.

\section{Podsumowanie}

Czytając po blisko stu latach opisy losów dzieci żyjących w czasach Janusza Korczaka, nie sposób oprzeć się refleksji, że mimo zmian cywilizacyjnych i warunków życia, wiele problemów dotyczy również dzieci współczesnych. Do tych ciągle nierozwiązanych kwestii należą problemy adaptacji umożliwiającej każdemu dziecku harmonijne dostosowywanie się do aktualnie obowiązujących zasad środowiskowych oraz nabywanie kompetencji sprzyjających wchodzeniu w dorosłość. Dotyczy to środowisk instytucjonalnych, jak również naturalnych. Instytucje wychowania zastępczego nie sprawdziły się zapewne w dużym stopniu dlatego, że w kolejnych dekadach w coraz większym stop-

109 A. Samsel, Wydolność wychowawcza rodzin najuboższych w Drugiej Rzeczypospolitej, w: Z zagadnień wychowania i opieki nad dzieckiem $w$ XVIII-XIX wieku, t. 2, red. O. Darewicz-Uberman, Wydawnictwo Uniwersytetu Jana Kochanowskiego, Kielce 2012, s. 303-306.

110 Ibidem, s. 306.

111 Ibidem, s. 307. 
niu odchodzono od tego, co swoim wychowankom oferował Korczak. Także dziś wiele dzieci pozostaje w środowiskach rodzin patologicznych, doznaje biedy i przemocy, co nierzadko odkrywają dopiero media w związku z tragediami, przybierającymi wymiary sensacji. Dziecięca „ulica” ciągle funkcjonuje, do tego środowiska w różny sposób adaptują się zarówno dzieci z rodzin patologicznych, jak i tych „,normalnie” zapracowanych, w których dziecko poza kluczem na szyi ma własny komputer, i-poda czy tablet.

Odwołując się do dzieł Korczaka, warto także zastanowić się nad trudami dzieciństwa, również tymi wiążącymi się z koniecznością ciągłej adaptacji do nowych środowisk. Dorosły nierzadko przez całe swoje dorosłe życie może pozostawać w jednym miejscu, dziecko musi natomiast ciągle i szybko dostosowywać się do zmian spowodowanych wiekiem, ale i konkretnymi realiami. Kiedy dostosuje się już do wymogów życia rodzinnego, pozna najbliższe środowisko lokalne, nierzadko musi otoczenie zmieniać, nie mając na te decyzje żadnego wpływu. Dorośli mogą je przemyśleć, dziecko musi się do nich dostosować. Szczególnie dramatyczny wymiar tych zmian łączy się z koniecznością opuszczenia środowiska własnej rodziny i adaptacją do środowisk wychowawczych zastępczych.

Konieczność adaptacji do nowych środowisk wymusza także edukacja. Zdecydowana większość współczesnych dzieci trafia do instytucji przedszkolnych, wszystkie do szkół. W tych ostatnich muszą szybko przystosować się do nowych wymogów, przy czym nie zawsze obowiązujące tam reguły są na tyle przejrzyste i przekonujące, by dziecko mogło je zaakceptować. Szkoła nadal wzbudza strach, w wielu przypadkach staje się źródłem wieloletnich nerwic i depresji. Nasila je dodatkowo niepokój o przyszłość, stres związany z wyborem kolejnych etapów edukacyjnych i pokonywaniem procedur kwalifikujących do ich realizacji. Korczak uczy i zaleca wrażliwość w rozwiązywaniu problemów, z jakimi dziecko musi się zmierzyć. Przekonuje również, jak ważna jest rola dorosłych, ich empatia, życzliwość, wsparcie ${ }^{112}$.

Posiłkując się dziełami Janusza Korczaka, warto także zastanowić się nad zdolnościami adaptacyjnymi z dziećmi będącymi wynikiem występującego między nimi zróżnicowania osobowościowego. Dla wszystkich ważne jest wsparcie dorosłych, ale potrzebują go w różnym stopniu. Szkodliwe dla rozwoju jest zarówno niedostrzeganie problemów dziecka, jak i nadmierne chronienie go przed ich doświadczaniem i rozwiązywaniem. W swojej pracy pedagogicznej Korczak opierał się na obserwacjach i diagnozach umożliwiających indywidualizację w wychowaniu i kształceniu. Indywidualizacja to również we współczesnej edukacji jeden z podstawowych wymogów, w teorii jednoznacznie akceptowanych, ale w praktyce często pomijanych. Wracając zatem do głównych założeń pedagogiki Korczaka, warto uświadomić sobie, że zindywidualizowane wspieranie rozwoju dziecka to nie wymysł współczesnych teoretyków, ale kontynuacja najbardziej wartościowych tradycji polskiej myśli o wychowaniu dziecka w domu, przedszkolu i szkole.

112 Dokumentacja Naszego Domu..., s. 297. 


\section{Bibliografia}

Bobrowska-Nowak W., Metoda obserwacji klinicznej w ujęciu Janusza Korczaka i jej znaczenie dla wspótczesnej pedagogiki, w: O pedagogikę jako naukę o człowieku w setnq rocznicę urodzin Janusza Korczaka, Uniwersytet Śląski, Katowice 1979.

Chodkowska M., Bednarz-Grzybek R., Twórczość i praktyka pedagogiczna Janusza Korczaka $w$ kontekście teorii socjologicznej Floriana Znanieckiego, Wydawnictwo UMCS, Lublin 2014.

Colman A. M., Stownik psychologii, Wydawnictwo Naukowe PWN, Warszawa 2009.

Dokumentacja Domu Sierot, w: Myśl pedagogiczna Janusza Korczaka. Nowe źródta, t. 2, wybór M. Falkowska, Nasza Księgarnia, Warszawa 1983.

Jakubowski M., Koncepcja Korczakowskiego samorzadu wychowawczego, w: O pedagogike jako naukę o człowieku w setna rocznicę urodzin Janusza Korczaka, Uniwersytet Śląski, Katowice 1979.

Januszewska E., Pedagogika Korczaka i współczesne problemy wychowania, „Problemy Opiekuńczo-Wychowawcze" 2003, nr 9, s. 56-58.

Korczak J., Życzliwość i niechęć, [,, Wychowanie Przedszkolne” 1933, nr 9, nr 4], w: idem, Wybór pism, t. 4, s. 375-379.

Korczak J., „Nasz Dom” (z „,Gazetki Światecznej”1921, nr 1/2, s. 9-11), w: idem, Prawidła życia. Publicystyka dla dzieci, Dzieła, t. 11, Międzynarodowe Stowarzyszenie im. Janusza Korczaka i Instytut Badań Literackich PAN, Warszawa 2003.

Korczak J., Bankructwo małego Dżeka, Towarzystwo Wydawnicze, Warszawa-Kraków 1924.

Korczak J., Dzieci i wychowanie, w: Tenże, Pisma wybrane, t. 3, wybór A. Lewin, Nasza Księgarnia, Warszawa 1978.

Korczak J., Dzieci ulicy, w: idem, Dzieci ulicy. Dziecko salonu, Dzieła, t. 1, red. H. Kirchner [i in.], Oficyna Wydawnicza Latona, Warszawa 1992.

Korczak J., Dziecko salonu, w: idem, Dzieci ulicy. Dziecko salonu. Dzieła, t. 1, red. H. Kirchner [i in.], Oficyna Wydawnicza Latona, Warszawa 1992.

Korczak J., Feralny tydzień, w: idem, Pisma wybrane, t. 3, wybór A. Lewin, Nasza Księgarnia, Warszawa 1978.

Korczak J., Internat, Kolonie letnie, Dom Sierot, w: Wybór pism pedagogicznych, t. 1, red. E. Frydman, Warszawa 1957.

Korczak J., Jak kochać dziecko, w: idem, Pisma wybrane, t. 1, wprowadzenie i wybór A. Lewin, Nasza Księgarnia, Warszawa 1978.

Korczak J., Jest szkoła, w: idem, Pisma wybrane, t. 3, wybór A. Lewin, Nasza Księgarnia, Warszawa 1978.

Korczak J., Kiedy znów będę maty, w: idem, Pisma wybrane, t. 3, Nasza Księgarnia, Warszawa 1978.

Korczak J., Kodeks Sądu Koleżeńskiego w Naszym Domu w Pruszkowie, „, Gazetka Świateczna” 1921, $n r$ 5, s. 36-39, w: idem, Prawidła życia. Publicystyka dla dzieci, Dzieła, t. 11, Międzynarodowe Stowarzyszenie im. Janusza Korczaka i Instytut Badań Literackich PAN, Warszawa 2003.

Korczak J., Król Maciuś Pierwszy: powieść, Towarzystwo Wydawnicze, Warszawa 1923.

Korczak J., Momenty wychowawcze, w: Pisma wybrane, t. 3, wybór A. Lewin, Nasza Księgarnia, Warszawa 1978.

Korczak J., Niepoprawni, [,,Szkoła Specjalna” 1931/1932, t. 8, nr 3], w: idem, Wybór pism, t. 4, wyboru dokonał I. Newerly, Nasza Księgarnia, Warszawa 1958.

Korczak J., O gazetce szkolnej, w: idem, Wybór pism, t. 4, wyboru dokonał I. Newerly, Nasza Księgarnia, Warszawa 1958.

Korczak J., Pamiętnik, w: idem, Wybór pism, t. 4, wyboru dokonał I. Newerly, Nasza Księgarnia, Warszawa 1958. 
Korczak J., Pedagogika żartobliwa, w: Wybór pism, t. 4, wyboru dokonał I. Newerly, Nasza Księgarnia, Warszawa 1958.

Korczak J., Stawa, w: J. Korczak, Stawa. Opowiadania (1898-1914), Dzieła, t. 6, red. H. Kirchner [i in.], Oficyna Wydawnicza Latona, Warszawa 1996.

Korczak J., Szkoła współczesna, w: idem, Pisma wybrane, t. 3, wybór A. Lewin, Nasza Księgarnia, Warszawa 1978.

Korczak J., Szkoła życia, w: idem, Pisma wybrane, t. 3, wybór A. Lewin, Nasza Księgarnia, Warszawa 1978.

Korczak J., Teoria a praktyka [,,Szkoła Specjalna” 1924/1925, nr 2], w: idem, Wybór pism, t. 4, wyboru dokonał I. Newerly, Nasza Księgarnia, Warszawa 1958.

Korczak J., Tęsknota [,,W Stońcu” 1920, nr 10-11], w: idem, Wybór pism, t. 4, wyboru dokonał I. Newerly, Nasza Księgarnia, Warszawa 1958.

Korczak J., Własność dziecka, [„Nasz Przegląd” 1927, nr 10], w: Myśl pedagogiczna Janusza Korczaka. Nowe Źródła, wybór M. Falkowska, t. 2, Nasza Księgarnia, Warszawa 1983.

Korczak J., Wychowawca ambitny, „Szkoła Specjalna”1938/1939, t. 15, nr 1, w: idem, Wybór pism, t. 4, wyboru dokonał I. Newerly, Nasza Księgarnia, Warszawa 1958.

Korczak J., Z naszego domu [,,W Stońcu” 1920, nr 1], w: idem, Wybór pism, t. 4, wyboru dokonał I. Newerly, Nasza Księgarnia, Warszawa 1958.

Król J., Koncepcja szkoły życia Janusza Korczaka, w: O pedagogike jako naukę o człowieku w setna rocznicę urodzin Janusza Korczaka, Uniwersytet Śląski, Katowice 1979.

Lewin A., Korczak znany i nieznany, EZOP; WSP ZNP, Warszawa 1999.

Lisowska E., Wprowadzenie do diagnozowania pedagogicznego, Wydawnictwo Uczelniane Wszechnica Świętokrzyska, Kielce 2003.

Łata A., Wczesne utwory literackie Janusza Korczaka jako przejaw ksztaltowania sie jego postawy patriotycznej, w: Życie i twórczość Janusza Korczaka jako temat filozoficzno-pedagogicznej refleksji, red. A. Tchorzewski, Wydawnictwo Uczelniane WSP Bydgoszcz, Bydgoszcz 1979.

Olczak-Ronikier J., Korczak. Próba biografii, W.A.B., Warszawa 2011.

Opowieść o Januszu Korczaku. Człowiek, który stat się legendą, IBIS, Poznań 2013.

Palczewska S., Respektowanie praw dziecka w placówkach opiekuńczo-wychowawczych, w: Dziecko w koncepcjach pedagogicznych Marii Grzegorzewskiej i Janusza Korczaka, red. J. Bałachowicz, Wydawnictwo Akademii Pedagogiki Specjalnej, Warszawa 2012.

Pamiętnik Towarzystwa „Pomoc dla Sierot” w Warszawie za rok 1913, Warszawa 1914.

Samsel A., Wydolność wychowawcza rodzin najuboższych w Drugiej Rzeczypospolitej, w: Z zagadnień wychowania i opieki nad dzieckiem w XVIII-XIX wieku, t. 2, red. O. Darewicz-Uberman, Wydawnictwo Uniwersytetu Jana Kochanowskiego, Kielce 2012.

Smolińska-Theiss B., Spuścizna pedagogiczna Janusza Korczaka. Pytania o uniwersalność i aktualność idei, w: Rok Janusza Korczaka 2012. Nie ma dzieci-sa ludzie, Biuro Rzecznika Praw Dziecka, Warszawa 2013.

Szlązakowa A., Humanistyczne wartości książek Janusza Korczaka dla dzieci i młodzieży, w: Życie i twórczość Janusza Korczaka jako temat filozoficzno-pedagogicznej refleksji, red. A. Tchorzewski, Wydawnictwo Uczelniane WSP Bydgoszcz, Bydgoszcz 1979.

Walczak G., Metody wychowania dziecka trudnego w ujęciu Janusza Korczaka, w: O pedagogike jako naukę o czlowieku w setna rocznicę urodzin Janusza Korczaka, Uniwersytet Śląski, Katowice 1979.

Wernik A., Wychowawcza funkcja publicystyki prasowej Janusza Korczaka dla dzieci w świetle materiałów z czasopisma , W słońcu”, w: O pedagogikę jako naukę o człowieku w setna rocznicę urodzin Janusza Korczaka, Uniwersytet Śląski, Katowice 1979. 
